\title{
Study of the impact of injection parameters on the performance of miscible sour gas injection for enhanced oil recovery
}

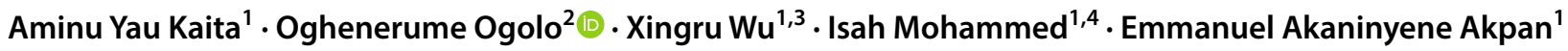

Received: 16 June 2019 / Accepted: 26 October 2019 / Published online: 5 December 2019

(c) The Author(s) 2019

\begin{abstract}
Sour gas reservoirs have faced critics for environmental concerns and hazards, necessitating a novel outlook to how the produced sour gases could be either utilized or carefully disposed. Over the years of research and practice, several methods of sour gas processing and utilization have been developed, from the solid storage of sulfur to reinjecting the sour gas into producing or depleted light oil reservoir for miscible flooding enhanced oil recovery. This paper seeks to investigate the impact of injection parameters on the performance of sour gas injection for enhance oil recovery. In designing a miscible gas flooding project, empirical correlations are used and the key parameter which impacts the phase behavior is identified to be the minimum miscibility pressure (MMP). A compositional simulator was utilized in this research work to study the effect of injection parameters such as minimum miscibility pressure, acid gas concentration, injection pressure and injection rate on the performance of miscible sour gas injection for enhanced oil recovery. The findings showed that methane concentration had a significant impact on the MMP of the process. Additionally, an increase in acid gas concentration decreases the MMP of the process as a result of an increase in gas viscosity, consequently extending the plateau period resulting in late gas breakthrough and increased overall recovery of the process.
\end{abstract}

Keywords Sour gas $\cdot$ Minimum miscibility pressure $\cdot$ Enhanced oil recovery $\cdot$ Process parameters $\cdot$ Acid gas

\section{Introduction}

A major cause for concern in the development of sour gas reservoir is the disposal of the produced gas (Xue et al. 2019). The gases are usually sweetened using different methods. Amine extraction is one of the most commonly used methods in the petroleum industries (Bennion et al. 1999; Chen 2016). The separation process results in the production of a waste stream composing of acid gases $\left(\mathrm{CO}_{2}\right.$ and $\left.\mathrm{H}_{2} \mathrm{~S}\right)$ and requires a huge capital and operation cost which has raised a cause of concern, given that the companies must

Oghenerume Ogolo

oghenerumeogolo@gmail.com

1 Department of Petroleum Engineering, African University of Science and Technology, Abuja, Nigeria

2 Department of Petroleum and Gas Engineering, Nile University of Nigeria, Abuja, Nigeria

3 Mewbourne School of Petroleum and Geological Engineering, Oklahoma University, Norman, USA

4 Petroleum Engineering Department, King Fahd University of Petroleum and Minerals, Dhahran, Saudi Arabia ensure their waste is eco-friendly before disposal (Bennion et al. 1999).

Over the years, a lot of strategies have been developed to handle acid gas mixture, with primary concerns being the reduction of the toxic hydrogen sulfide gas to an inert/ non-toxic reactive product (Bennion et al.1999). The most common technique is the Claus reaction process where gases containing $\mathrm{H}_{2} \mathrm{~S}$ are catalytically converted to elemental sulfur (Bennion et al. 1999). Also, a viable alternative is the reinjection of the produced gas into the reservoir as an enhanced recovery technique or for storage (Abou-Sayed et al. 2004; Bhatti et al. 2019; Ceragioli and Gianelli 2008; Ghoodjani and Bolouri 2011; Hawez and Ahmed 2014; Nwidee et al. 2016). However, concerns have been raised as to possible leakages to the surfaces through faults or unsealing traps.

Sour gas injection for enhance oil recovery (EOR) is a viable option that presents a solution to many problems currently in the industry. It eliminates current taxation or future liability associated with emission or surface storage of sulfur (Abou-Sayed et al. 2004). EOR programs using gas injection have shown that sour gas has better sweep efficiency 
and voidage replacement ability compared to other gases used for miscible injection EOR. Therefore, this increases the amount of recoverable hydrocarbon (Abou-Sayed et al. 2004; Al-Hadhrami et al. 2007; Battistelli et al. 2011; Chugh et al. 2006; Metcalfe et al. 1973). This also translates to better economics as the cost of many surface treatments is eliminated, thus reducing the operational cost of the process.

This research work seeks to provide insight into the impact of injection parameters on the viability of miscible flooding of a light oil reservoir by the reinjection of sour gas (Abou-Sayed et al. 2004; Benham et al. 1960; Christiansen and Haines 1987; Eakin 1988; Elsharkawy et al. 1992; Green and Willhite 1998; Haynes et al. 2008; Holm and Josendal 1974; Khan et al. 2013; Lake 1989; Orr and Silva 1987; Orr et al. 1982). The reinjection of a rich waste acid gas stream directly into the producing light oil reservoir for the purpose of miscible flooding enhanced oil recovery using numerical simulation was studied putting into consideration the impact of certain injection parameters on the overall performance of the recovery process.

\section{Methodology and model description}

This section presents the reservoir model description, detailed methodologies and procedures used in achieving the aim and objectives of this research work. A comparative study of MMP using correlations was carried out. Base case light oil reservoir model was built using Eclipse 300 which is a compositional simulator, and the performance of sour gas injected was evaluated by varying the composition of acid gas injected in the oil recovery. The effect of the gas injection rate and injection parameter on the field production was also studied.

\section{Base case model description}

The reservoir model used in this study was based on the reservoir studies carried out by Battistelli et al. 2011. The fluid composition, porosity and initial water saturation are the same as reported. Other parameters such as permeability, grid, reservoir pressure and temperature were assumed. The base case model is a homogeneous reservoir with both porosity and permeability uniform in all directions, and the model was built using ECLIPSE 300 which is a compositional simulator. The model consists of two wells, one producer and one injector. The base case model has a length of $1320 \mathrm{ft}$, a width of $1320 \mathrm{ft}$ and a thickness of $10 \mathrm{ft}$, and major reservoir parameters are summarized in Table 1. Peng-Robinson EoS is used in fluid characterization, and the component properties are summarized in Table 1. The injection fluid composition is shown in Table 2.

\section{Reservoir model initialization}

The reservoir model was initialized to determine the initial conditions of the reservoir. The gas-oil contact was set far above the reservoir so that only the hydrocarbon content is considered for study; the water-oil contact is set at $100 \mathrm{ft}$ below the reference depth. Table 3 shows the reservoir model input parameters, while Table 4 shows the phase binary interaction parameters for the components contained in the oil mixture. Table 5 shows the oil, water and gas saturation functions.

\section{Comparative study of MMP using correlations}

This study made use of the existing pure and impure $\mathrm{CO}_{2}$ stream MMP correlations published in the literature. Three injection scenarios (Table 6) were considered to evaluate the general trend on how MMP changes with a decrease in $\mathrm{C}_{1}$ composition.

Table 1 Reservoir fluid composition and pseudo-component properties at $100{ }^{\circ} \mathrm{C}\left(212^{\circ} \mathrm{F}\right)$ (Battistelli et al. 2011)

\begin{tabular}{|c|c|c|c|}
\hline \multicolumn{3}{|l|}{ Component } & Mole fraction \\
\hline \multicolumn{4}{|c|}{ Reservoir fluid composition } \\
\hline $\mathrm{H}_{2} \mathrm{~S}$ & & \multicolumn{2}{|c|}{0.1500} \\
\hline $\mathrm{CO}_{2}$ & & \multicolumn{2}{|c|}{0.0500} \\
\hline $\mathrm{C} 1$ & & \multicolumn{2}{|c|}{0.4500} \\
\hline $\mathrm{C} 2$ & & \multicolumn{2}{|c|}{0.0500} \\
\hline $\mathrm{C} 3$ & & \multicolumn{2}{|c|}{0.0500} \\
\hline $\mathrm{C} 5$ & & \multicolumn{2}{|c|}{0.0500} \\
\hline C6+ & & \multicolumn{2}{|c|}{0.1000} \\
\hline $\mathrm{C} 9+$ & & \multicolumn{2}{|c|}{0.0939} \\
\hline $\mathrm{H} 20$ & & \multicolumn{2}{|c|}{0.0061} \\
\hline C6+ & & \multicolumn{2}{|l|}{$\mathrm{C} 9+$} \\
\hline \multicolumn{4}{|c|}{ Pseudo-component properties } \\
\hline Molecular weight & 93.00 & Molecular weight & 250.00 \\
\hline Specific gravity & 0.29 & Specific gravity & 0.73 \\
\hline
\end{tabular}

Table 2 Injection fluid composition

\begin{tabular}{ll}
\hline Component & Mole fraction \\
\hline Injection fluid composition at $100{ }^{\circ} \mathrm{C}$ & \\
$\mathrm{H}_{2} \mathrm{~S}$ & 0.0735 \\
$\mathrm{CO}_{2}$ & 0.0744 \\
$\mathrm{C} 1$ & 0.8384 \\
$\mathrm{C} 2$ & 0.0130 \\
$\mathrm{C} 3$ & 0.0007 \\
\hline
\end{tabular}


Table 3 Reservoir model input parameters

\begin{tabular}{|c|c|c|c|c|}
\hline \multicolumn{3}{|l|}{ Parameter } & & Value \\
\hline \multicolumn{5}{|c|}{ Base case model input parameter } \\
\hline \multicolumn{5}{|c|}{ Grid } \\
\hline \multicolumn{4}{|l|}{ Cells } & $\mathrm{Nx}=30, \mathrm{Ny}=30, \mathrm{Nz}=5$ \\
\hline \multicolumn{4}{|c|}{ Cells dimension } & $D x=44 \mathrm{ft}, D y=44 \mathrm{ft}, \mathrm{Dz}=2 \mathrm{ft}$ \\
\hline \multicolumn{4}{|c|}{ Injection cells } & $\mathrm{Nx}=1, \mathrm{Ny}=1, \mathrm{Nz}=1$ \\
\hline \multicolumn{4}{|c|}{ Production cells } & $\mathrm{Nx}=30, \mathrm{Ny}=30, \mathrm{Nz}=5$ \\
\hline \multicolumn{4}{|c|}{ Porosity } & 0.2 \\
\hline \multicolumn{4}{|l|}{ Permeability } & $K_{\mathrm{v}}=15 \mathrm{md}, K_{\mathrm{h}}=15 \mathrm{md}$ \\
\hline \multicolumn{4}{|c|}{ Reservoir temperature } & $212^{\circ} \mathrm{F}$ \\
\hline \multicolumn{4}{|c|}{ Reservoir pressure } & $5169 \mathrm{psi}$ \\
\hline \multicolumn{4}{|c|}{ Wellbore radius } & $0.3 \mathrm{ft}$ \\
\hline \multicolumn{4}{|c|}{ Oil production rate } & Unlimited \\
\hline \multicolumn{4}{|c|}{ Gas production rate } & $1000 \mathrm{Mscf} /$ day \\
\hline \multicolumn{4}{|c|}{ Production well BHP } & $2000 \mathrm{psi}$ \\
\hline \multicolumn{4}{|c|}{ Gas injection rate } & $2000 \mathrm{Mscf}$ \\
\hline Injection wel & & & & $5200 \mathrm{psi}$ \\
\hline Simulation ti & & & & 800 days \\
\hline Water proper & & & & \\
\hline Compressibil & & & & $3.0 \times 10^{-6}$ \\
\hline Density (lbm & & & & 63 \\
\hline Rock compre & & & & $4.0 \times 10^{-6}$ \\
\hline Viscosity $(\mathrm{cP}$ & & & & 0.31 \\
\hline Component & Critical temperature $\left({ }^{\circ} \mathrm{F}\right)$ & Critical pressure (Psi) & Molecular weight & Compressibility \\
\hline Component $p$ & & & & \\
\hline $\mathrm{CO}_{2}$ & 548.460 & 1071.330 & 44.010 & 0.274077 \\
\hline $\mathrm{H}_{2} \mathrm{~S}$ & 672.480 & 1296.170 & 34.0760 & 0.281954 \\
\hline $\mathrm{H}_{2} \mathrm{O}$ & 473.240 & 1447.640 & 18.010 & 0.275389 \\
\hline $\mathrm{C}_{1}$ & 343.080 & 667.781 & 16.043 & 0.284729 \\
\hline $\mathrm{C}_{2}$ & 549.770 & 708.342 & 30.070 & 0.284634 \\
\hline $\mathrm{C}_{3}$ & 665.640 & 615.758 & 44.097 & 0.276164 \\
\hline $\mathrm{C}_{5}$ & 838.620 & 487.169 & 72.151 & 0.268808 \\
\hline $\mathrm{C}_{6+}$ & 957.030 & 469.530 & 93.000 & 0.272489 \\
\hline $\mathrm{C}_{9+}$ & 1389.100 & 207.897 & 250.000 & 0.220257 \\
\hline
\end{tabular}

\section{First scenario}

In this scenario, the injection gas consists of only $\mathrm{CO}_{2}$ and $\mathrm{C}_{1}$. Two different correlations used in this case were Yuan et al. correlation and Glaso correlation. MMP was calculated as $\mathrm{C}_{1}$ composition decreases and $\mathrm{CO}_{2}$ composition increases. MMP for pure $\mathrm{CO}_{2}$ was calculated first using the two correlations: For Glaso correlation, the MMP is a function of reservoir temperature and intermediate component composition in the reservoir oil $\left(\mathrm{C}_{2}-\mathrm{C}_{6}\right)$ (Glaso 1985), while for Yuan et al. correlation, the MMP is a function of the molecular weight of $\mathrm{C}_{7+}$, molar percentage of intermediates and reservoir temperature. The limitation of this correlation is that the oil used for the regression has a molecular weight of $\mathrm{C}_{7+}$ in the range of 140-245, whereas the oil in the reservoir studied has $\mathrm{M}_{\mathrm{C} 7+}$ of 250 . Also, the molar percentage of the intermediates is between 11.3 and $40.3 \%$ and reservoir temperature ranges from 120 to $300{ }^{\circ} \mathrm{F}$ (Yuan et al. 2004). The fraction of impure and pure MMP is calculated using the Yuan et al. correlation from which the impure MMP for the two correlations was calculated.

\section{Second scenario}

In this case, the injection gas consists of three components as listed in Table 6 . The injection gas composition changes by decreasing $\mathrm{C}_{1}$ and increasing $\mathrm{H}_{2} \mathrm{~S}$ and $\mathrm{CO}_{2}$ compositions. $\mathrm{CO}_{2}$ and $\mathrm{H}_{2} \mathrm{~S}$ compositions were increased equally. Two 
Table 4 NA phase binary interaction parameters for the components contained in the oil mixture

\begin{tabular}{|c|c|c|c|c|c|c|c|c|c|}
\hline NA-kij & $\mathrm{CO}_{2}$ & $\mathrm{H}_{2} \mathrm{~S}$ & $\mathrm{H}_{2} \mathrm{O}$ & $\mathrm{C}_{1}$ & $\mathrm{C}_{2}$ & $\mathrm{C}_{3}$ & $\mathrm{C}_{5}$ & $\mathrm{C}_{6+}$ & $\mathrm{C}_{9+}$ \\
\hline \multicolumn{10}{|l|}{$\mathrm{CO}_{2}$} \\
\hline $\mathrm{H}_{2} \mathrm{~S}$ & 0.0960 & & & & & & & & \\
\hline $\mathrm{H}_{2} \mathrm{O}$ & 0 & 0 & & & & & & & \\
\hline $\mathrm{C}_{1}$ & 0.1000 & 0.0500 & 0 & & & & & & \\
\hline $\mathrm{C}_{2}$ & 0.1000 & 0.0500 & 0 & 0 & & & & & \\
\hline $\mathrm{C}_{3}$ & 0.1000 & 0.0500 & 0 & 0 & 0 & & & & \\
\hline $\mathrm{C}_{5}$ & 0.1000 & 0.0500 & 0 & 0 & 0 & 0 & & & \\
\hline $\mathrm{C}_{6+}$ & 0.1000 & 0.0500 & 0 & 0.0326 & 0.0100 & 0.0100 & 0 & & \\
\hline $\mathrm{C}_{9+}$ & 0.1000 & 0.0500 & 0 & 0.0512 & 0.0100 & 0.0100 & 0 & 0 & 0 \\
\hline
\end{tabular}

Table 5 Oil, water and gas saturation functions

\begin{tabular}{lllllllll}
\hline$S_{\mathrm{W}}$ & $K_{\mathrm{RW}}$ & $P_{\mathrm{COW}}$ & $S_{\mathrm{O}}$ & $K_{\mathrm{ROW}}$ & $K_{\mathrm{ROG}}$ & $S_{\mathrm{G}}$ & $K_{\mathrm{RG}}$ & $P_{\mathrm{COG}}$ \\
\hline 0.200 & 0 & 0 & 0 & 0 & 0 & 0 & 0 & 0 \\
0.240 & 0.003 & 0 & 0.300 & 0 & 0 & 0.050 & 0 & 0 \\
0.280 & 0.010 & 0 & 0.330 & 0.005 & 0.005 & 0.100 & 0.004 & 0 \\
0.320 & 0.023 & 0 & 0.360 & 0.018 & 0.018 & 0.150 & 0.015 & 0 \\
0.360 & 0.040 & 0 & 0.390 & 0.038 & 0.038 & 0.200 & 0.033 & 0 \\
0.400 & 0.063 & 0 & 0.420 & 0.064 & 0.064 & 0.250 & 0.059 & 0 \\
0.440 & 0.090 & 0 & 0.450 & 0.096 & 0.096 & 0.300 & 0.093 & 0 \\
0.480 & 0.123 & 0 & 0.480 & 0.133 & 0.133 & 0.350 & 0.133 & 0 \\
0.520 & 0.160 & 0 & 0.510 & 0.175 & 0.175 & 0.400 & 0.181 & 0 \\
0.560 & 0.203 & 0 & 0.540 & 0.223 & 0.223 & 0.450 & 0.237 & 0 \\
0.600 & 0.250 & 0 & 0.570 & 0.275 & 0.275 & 0.500 & 0.300 & 0 \\
0.640 & 0.303 & 0 & 0.600 & 0.333 & 0.333 & 0.550 & 0.370 & 0 \\
0.680 & 0.360 & 0 & 0.630 & 0.395 & 0.395 & 0.600 & 0.448 & 0 \\
0.720 & 0.423 & 0 & 0.660 & 0.462 & 0.462 & 0.650 & 0.533 & 0 \\
0.760 & 0.490 & 0 & 0.690 & 0.533 & 0.533 & 0.700 & 0.626 & 0 \\
0.800 & 0.563 & 0 & 0.720 & 0.609 & 0.609 & 0.750 & 0.726 & 0 \\
0.840 & 0.640 & 0 & 0.750 & 0.69 & 0.690 & 0.800 & 0.834 & 0 \\
0.880 & 0.723 & 0 & 0.780 & 0.775 & 0.775 & & & \\
0.920 & 0.810 & 0 & 0.800 & 0.834 & 0.834 & & & \\
0.960 & 0.903 & 0 & & & & & & \\
1.000 & 1.000 & 0 & & & & & & \\
\hline
\end{tabular}

Table 6 Different scenarios for MMP studies

\begin{tabular}{lll}
\hline Scenario & Component in injection gas & $\begin{array}{l}\text { Com- } \\
\text { position } \\
(\%)\end{array}$ \\
\hline First scenario & $\mathrm{CO}_{2}+\mathrm{C}_{1}$ & 100 \\
Second scenario & $\mathrm{CO}_{2}+\mathrm{H}_{2} \mathrm{~S}+\mathrm{C}_{1}$ & 100 \\
Third scenario & $\mathrm{H}_{2} \mathrm{~S}+\mathrm{C}_{1}$ & 100 \\
\hline
\end{tabular}

correlations were used for this study: Yuan et al. and Glaso correlation for the estimation of pure $\mathrm{CO}_{2} \mathrm{MMP}$; for the impure/pure MMP fraction, Sebastian et al. and Yuan et al. were used, while the impure MMP was calculated using Glaso and Yuan et al. correlation.

\section{Third scenario}

In this case, only $\mathrm{H}_{2} \mathrm{~S}$ and $\mathrm{C}_{1}$ are present in the injection gas. The goal here is to understand how $\mathrm{H}_{2} \mathrm{~S}$ affects the MMP. Correlation for estimating hydrocarbon gas MMP and impure $\mathrm{CO}_{2}$ stream was used to calculate the MMP. The Glaso correlation for hydrocarbon gas is the best option because it accounts for the change in $\mathrm{C}_{1}$ composition in the injected gas which corresponds to the objective of this study. The Yuan et al. correlation was used for the impure $\mathrm{CO}_{2}$ stream for comparison purpose. 


\section{Compositional variation of acid gas in the injection gas}

It is important to determine how acid gas composition in the injection gas affects oil recovery as this will help to understand how the gas helps to improve recovery in a gas injection process. A 15-mole percent acid gas is used for the base case model with an equal composition for $\mathrm{H}_{2} \mathrm{~S}$ and $\mathrm{CO}_{2}$ (i.e., $7.5 \%$ of $\mathrm{H}_{2} \mathrm{~S}$ and $7.5 \% \mathrm{CO}_{2}$ ). $\mathrm{C}_{1}$ makes up $80 \%$ of the injection gas, $0.0061 \%$ water, while $\mathrm{C}_{2}-\mathrm{C}_{5}$ makes up the remaining percentage as shown in Table 6 . The composition of acid gas was varied subsequently from $15-20 \%, 30 \%$ and $40 \%$. Also, three different cases were further considered to see the effect of injecting pure $\mathrm{CO}_{2}$ (case one), a mix of $50 \%$ acid gas and $50 \% \mathrm{C}_{1}$ (case two) and pure acid gas having $50 \% \mathrm{CO}_{2}$ and $50 \% \mathrm{H}_{2} \mathrm{~S}$ (case three) on the oil production rate and recovery efficiency, respectively, considering miscibility conditions.

\section{Effect of gas injection rate}

This study helps to also understand how gas injection rate affects various parameters such as oil recovery, oil production rate and how the volume of gas injected increases oil recovery. For this study, three rates were used to compare with the base case model. The injection was changed from 500 to 3000 Mscf to compare with the base case of 2000 Mscf.

\section{Injection pressure effect}

In this part of the study, the effect of injection pressure on the oil recovery from the model was investigated. Injection and production wells are completed in the first and fifth layer, respectively. For this investigation, two different pressures were used representing low case and high case to compare with the base case model.

For low case, an injection pressure of 2500 psia was used. This pressure was used to simulate immiscible gas injection, while for the high case, an injection pressure of 7500 psia was used which simulates first contact miscible injection. Based on the MMP study done, the estimated MMP using the equation of state analytical method in Eclipse PVTi is approximately 6200 psia for first contact miscibility and 5000 psia for multi-contact miscibility. Simulation runs were conducted at pressures below, equal to and greater than this pressure as stated above.

Since in vaporizing drive mechanisms, the pressure at the miscible front should be greater than the predicted miscible pressure, injection of gas at 5200 psi will raise the average reservoir pressure from initial pressure to the miscibility pressure of 5000 psi. Therefore, the injection pressure of
5200 psi seems to be the best candidate for the base case model.

\section{Results and discussions}

\section{Comparative study of MMP using correlations}

\section{First scenario}

The fraction of impure and pure MMP was calculated using the Yuan et al. correlation and Glaso correlation from which the impure MMP for the two correlations was calculated as seen in Table 7. Both correlations gave a similar trend; the MMP decreases as $C_{1}$ composition decreases as shown in Figs. 1 and 2. The decrease in the MMP as methane composition increased was due to the nature of $t$ methane gas. It is lighter and has a low viscosity. It will form a lesser density gas mixture. Utilization of only methane gas requires a very high MMP to attain miscibility for oil trapped in already depleted reservoir. But mixing it with $\mathrm{CO}_{2}$ will lower the MMP required. This is indeed the very reason why there is a decrease in the MMP as the concentration of methane in the injection gas increases.

\section{Second scenario}

Table 8 shows the result of the MMP studies obtained from scenario two, while Figs. 3 and 4 show the results of the second scenario MMP study using the Glaso correlation and Yuan et al. correlation, respectively. Both figures show a linear relationship between $\mathrm{C}_{1}$ composition and MMP. This scenario shows a trend similar to the first scenario which further confirms the effect of $\mathrm{C}_{1}$ on MMP. Just as in the first scenario, the Glaso correlation has a more conservative result as compared to Yuan et al. correlation. Comparing the result of the two scenarios, the MMP of the second scenario is higher which is due to the presence of $\mathrm{H}_{2} \mathrm{~S}$. $\mathrm{CO}_{2}$ is denser

Table 7 Result of MMP studies for scenario one

\begin{tabular}{llll}
\hline $\mathrm{CO}_{2}(\%)$ & $\mathrm{C}_{1}(\%)$ & Glaso (Psi) & Yuan et al. (psi) \\
\hline 10 & 90 & 6799 & 7948 \\
20 & 80 & 6392 & 7473 \\
30 & 70 & 5987 & 6998 \\
40 & 60 & 5580 & 6524 \\
50 & 50 & 5174 & 6049 \\
60 & 40 & 4768 & 5574 \\
70 & 30 & 4362 & 5100 \\
80 & 20 & 3956 & 4625 \\
90 & 10 & 3550 & 4150 \\
100 & 0 & 3144 & 3675 \\
\hline
\end{tabular}


Fig. 1 Scenario 1 MMP change with $\mathrm{C} 1$ composition using Glaso correlation
Fig. 2 Scenario 1 MMP change with $\mathrm{C}_{1}$ composition using Yuan et al. correlation
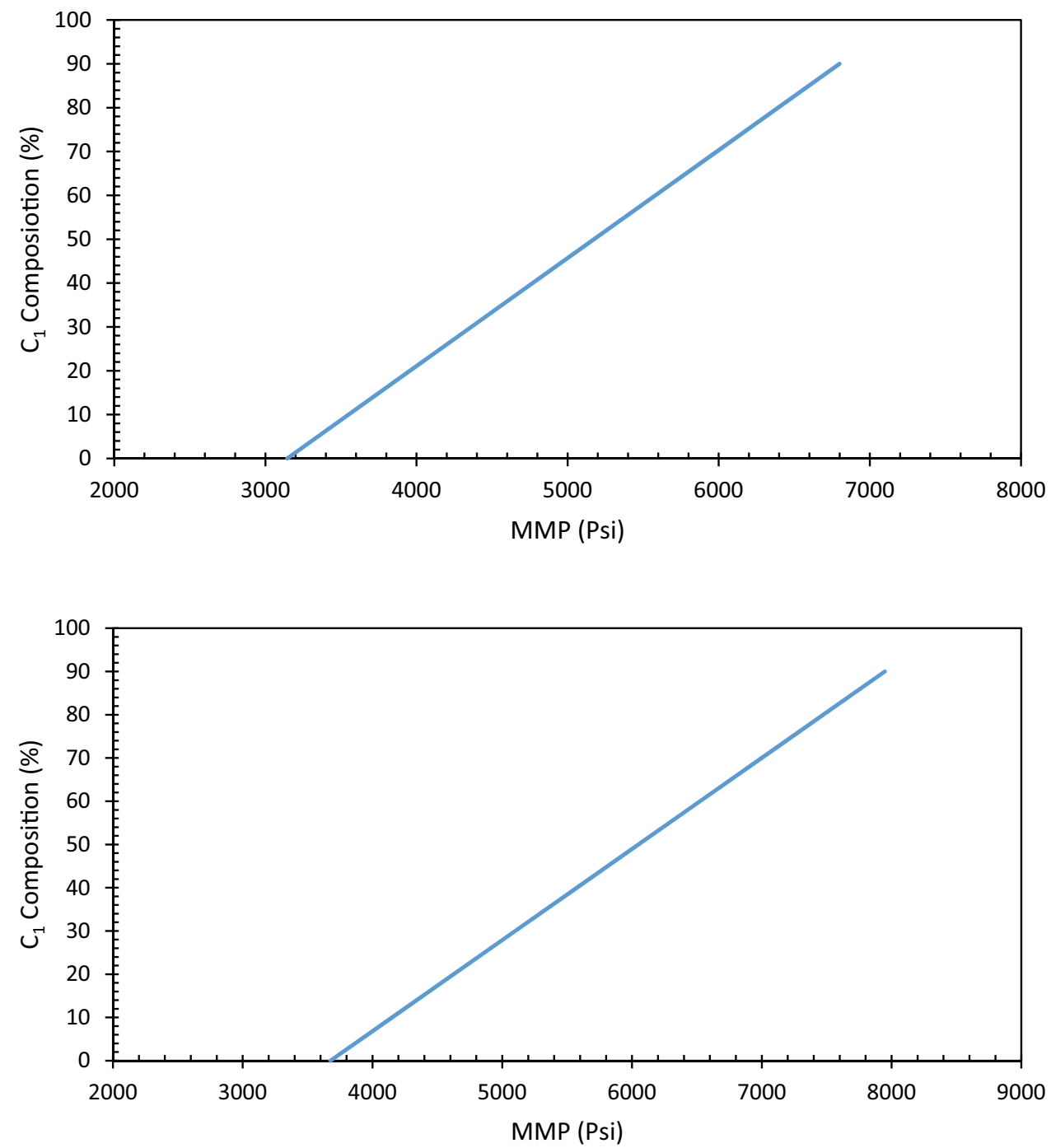

Table 8 Result of MMP studies for scenario two

\begin{tabular}{lccll}
\hline $\mathrm{H}_{2} \mathrm{~S}$ & $\mathrm{CO}_{2}$ & $\mathrm{C}_{1}$ & Glaso (Psi) & Yuan et al. (Psi) \\
\hline 5 & 5 & 90 & 7002 & 8185 \\
10 & 10 & 80 & 6799 & 7948 \\
15 & 15 & 70 & 6595 & 7710 \\
20 & 20 & 60 & 6392 & 7473 \\
25 & 25 & 50 & 6189 & 7236 \\
30 & 30 & 40 & 5986 & 6998 \\
35 & 35 & 30 & 5783 & 6761 \\
40 & 40 & 20 & 5580 & 6524 \\
45 & 45 & 10 & 5377 & 6286 \\
50 & 50 & 0 & 5174 & 6049 \\
\hline
\end{tabular}

than $\mathrm{H}_{2} \mathrm{~S}$, and the addition of $\mathrm{H}_{2} \mathrm{~S}$ leads to an increment in the MMP as compared to scenario one. Similarly, an increment of the percentage of methane leads to an increment in the MMP.

\section{Third scenario}

Table 9 shows the results of the MMP studies obtained from scenario three, while Figs. 5 and 6 show the MMP trend for the third scenario using the Glaso correlation and Yuan et al. correlation, respectively. It is seen that the Glaso correlation gave a more realistic MMP as compared to Yuan et al. correlation. The MMP values obtained using the Yuan et al. correlation were higher than the ones obtained in scenario one and scenario two making it unrealistic. This is because Yuan et al. correlation is designed for a $\mathrm{CO}_{2}$ stream with impurities which is not true for this case. However, the MMP trend obtained for this scenario using the Glaso correlation and Yuan et al. correlation was a parabolic trend unlike scenario one and scenario two where the trend obtained was a linear trend. This could be associated with the fact that both correlations used are not a perfect match for the case under investigation. The Glaso correlation is designed for gas injection with intermediates 
Fig. 3 Scenario 2 MMP change with $\mathrm{C}_{1}$ composition using Glaso correlation

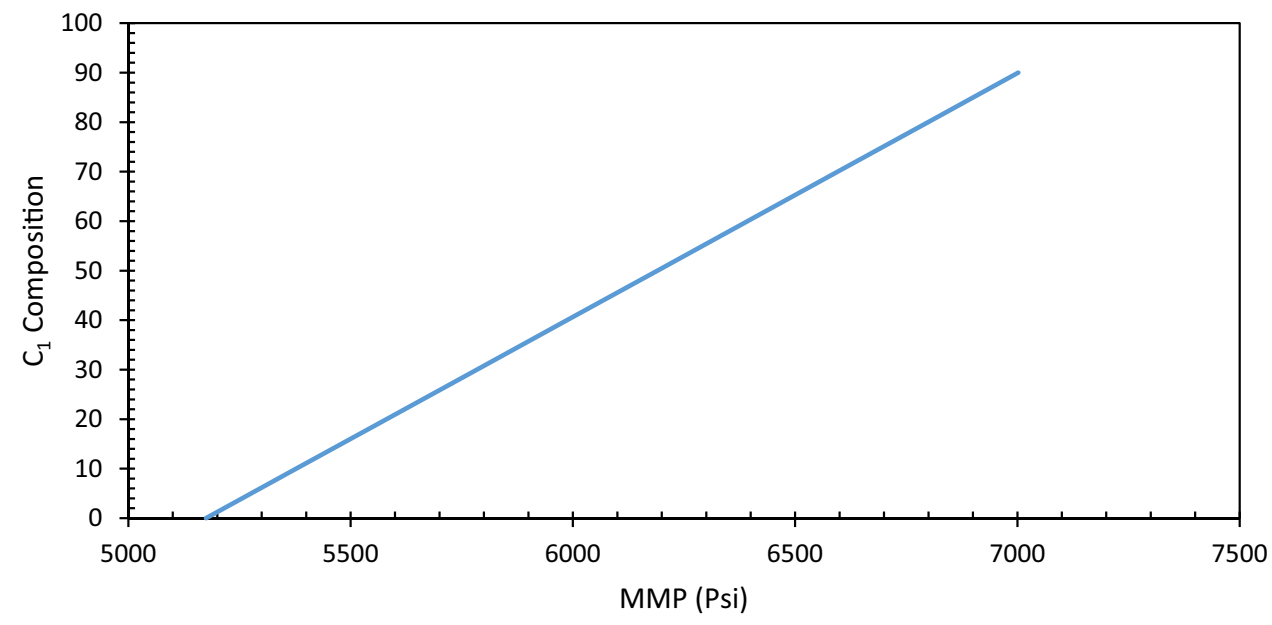

Fig. 4 Scenario 2 MMP change with $\mathrm{C}_{1}$ composition using Yuan et al. correlation

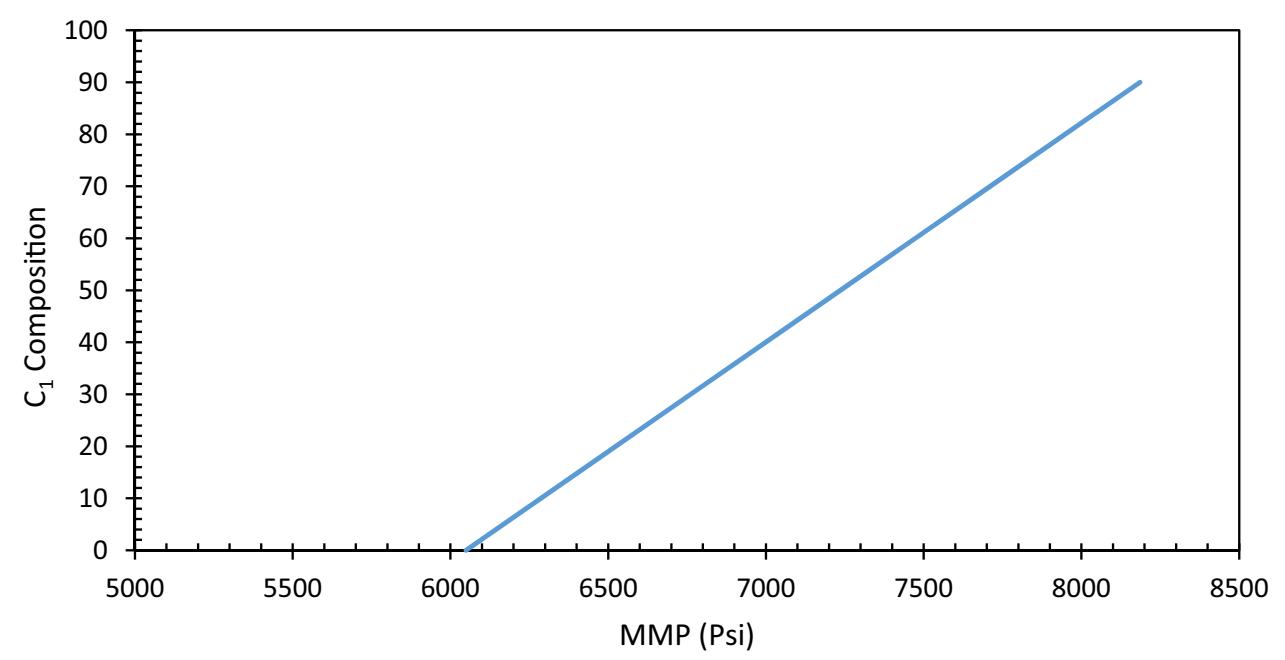

Table 9 Result of MMP studies for scenario three

\begin{tabular}{lccc}
\hline $\mathrm{H}_{2} \mathrm{~S}$ & $\mathrm{C}_{1}$ & Glaso (Psi) & Yuan et al. (Psi) \\
\hline 10 & 90 & 10020 & 28,175 \\
20 & 80 & 7029 & 23,835 \\
30 & 70 & 5027 & 19,928 \\
40 & 60 & 3696 & 16,442 \\
50 & 50 & 2823 & 13,366 \\
60 & 40 & 2260 & 10,686 \\
70 & 30 & 1908 & 8389 \\
80 & 20 & 1700 & 6464 \\
90 & 10 & 1590 & 4897 \\
100 & 0 & 1546 & 3675 \\
\hline
\end{tabular}

component $\left(\mathrm{C}_{2}-\mathrm{C}_{6}\right)$ of molecular weight of 34 which is not the case here. The MMP also increased with reduction in the composition of methane due to the nature and density of methane as observed in the first scenario.

\section{Base case model description and initialization}

The base case reservoir model used in this study is shown in Fig. 7. From the model initialization result, the initial field pressure of the reservoir was 5169 psi at a reference depth of $9840 \mathrm{ft}$, which corresponds to the top of the reservoir. From Table 3, a simple calculation shows that the reservoir has a pore volume of $620,160 \mathrm{rb}$, with an initial hydrocarbon pore volume of $496,128 \mathrm{rb}$. The original oil in place, water in place and gas in place were $216050 \mathrm{STB}, 124,128 \mathrm{rb}$ and $570.803 \mathrm{Mscf}$, respectively. The reservoir has an initial GOR of 2.642 Mscf/STB and FVF of $2.298 \mathrm{rb} / \mathrm{STB}$.

\section{Compositional variation of acid gas in the injection gas}

Figure 8 shows the effect of acid gas compositional variation on oil recovery efficiency. The result shows that the increase in acid gas concentration leads to an increase in oil recovery. 
Fig. 5 MMP trend with changing $\mathrm{C}_{1}$ composition using Glaso correlation

Fig. 6 MMP trend with changing $\mathrm{C}_{1}$ composition using Yuan et al. correlation
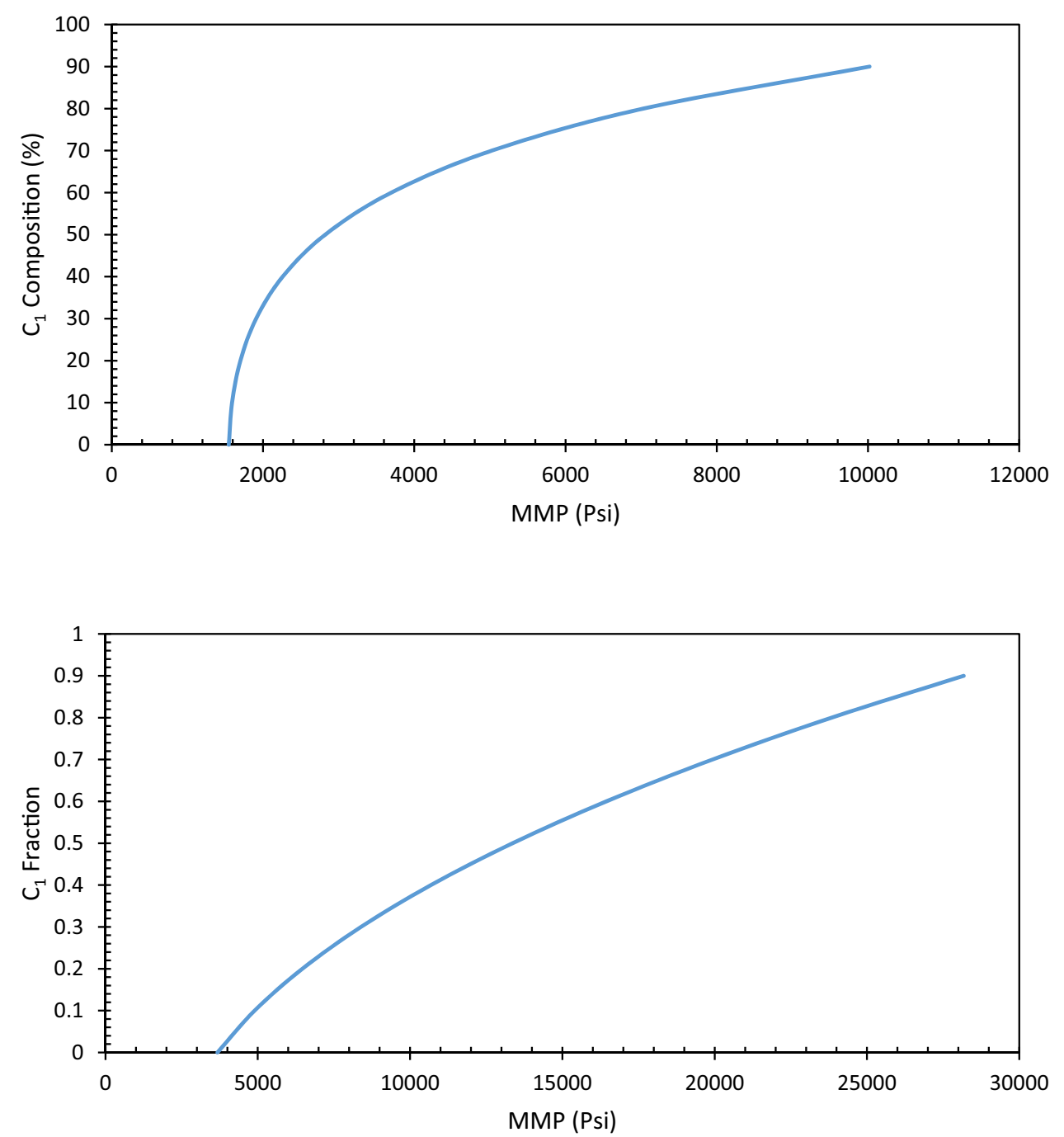

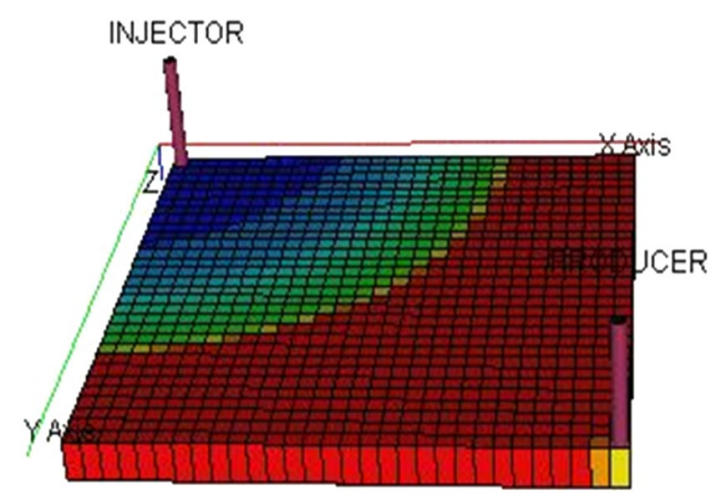

Fig. 7 Model diagram

An overall recovery of 86.81 and $78 \%$ was achieved when $40.30 \%$ and $20 \%$ acids gas composition, respectively, were used. It is also observed that the injection gas with the lower composition of acid gas had the earliest breakthrough time, while the injection gas with the highest composition had the least breakthrough time. The increase in the recovery of oil and delay of the breakthrough time as the composition of the acid gas was increased was as a result of the increment in the density and viscous nature of the injection gas. The acid gas increased the density and viscosity of the injected gas.

Figure 9 shows how acid gas composition affects oil production rate. The result clearly shows that as the composition of acid gas increases the gas breakthrough time also increases. Initially, there was a decrease in the oil production rate, but after about 40 days of injecting the sour gas, the reservoir began to feel the effect of the injection leading to an increment in the production rate. The injection gas with $15 \%$ acid gas composition had the least breakthrough time, and the injection gas with $40 \%$ acid gas had the highest breakthrough time. This is because as the composition of acid gas increases in the injection gas, the viscosity of the injection gas also increases leading to a decrease in the mobility of the injected gas.

Figure 10 shows the effect of acid gas composition on the oil production rate. The first down dip is when the reservoir 


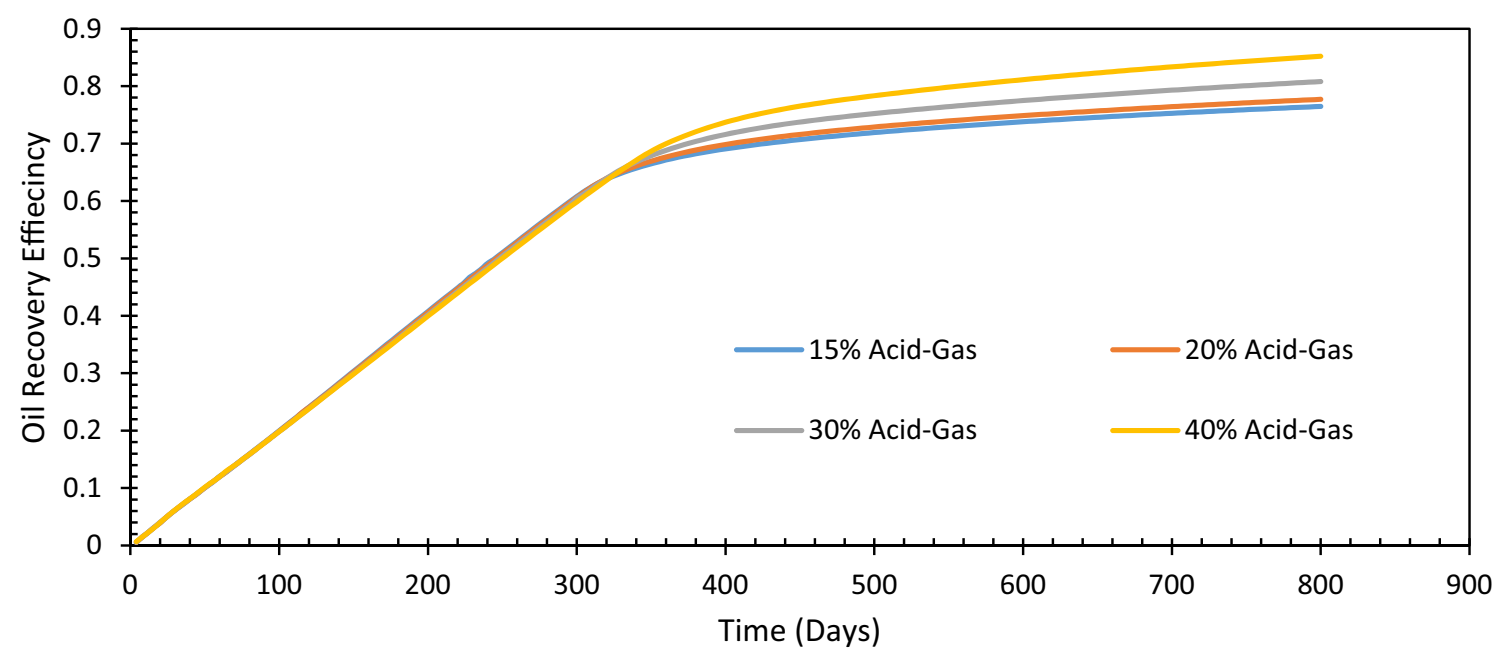

Fig. 8 Comparison of the effect of acid gas composition on oil recovery efficiency

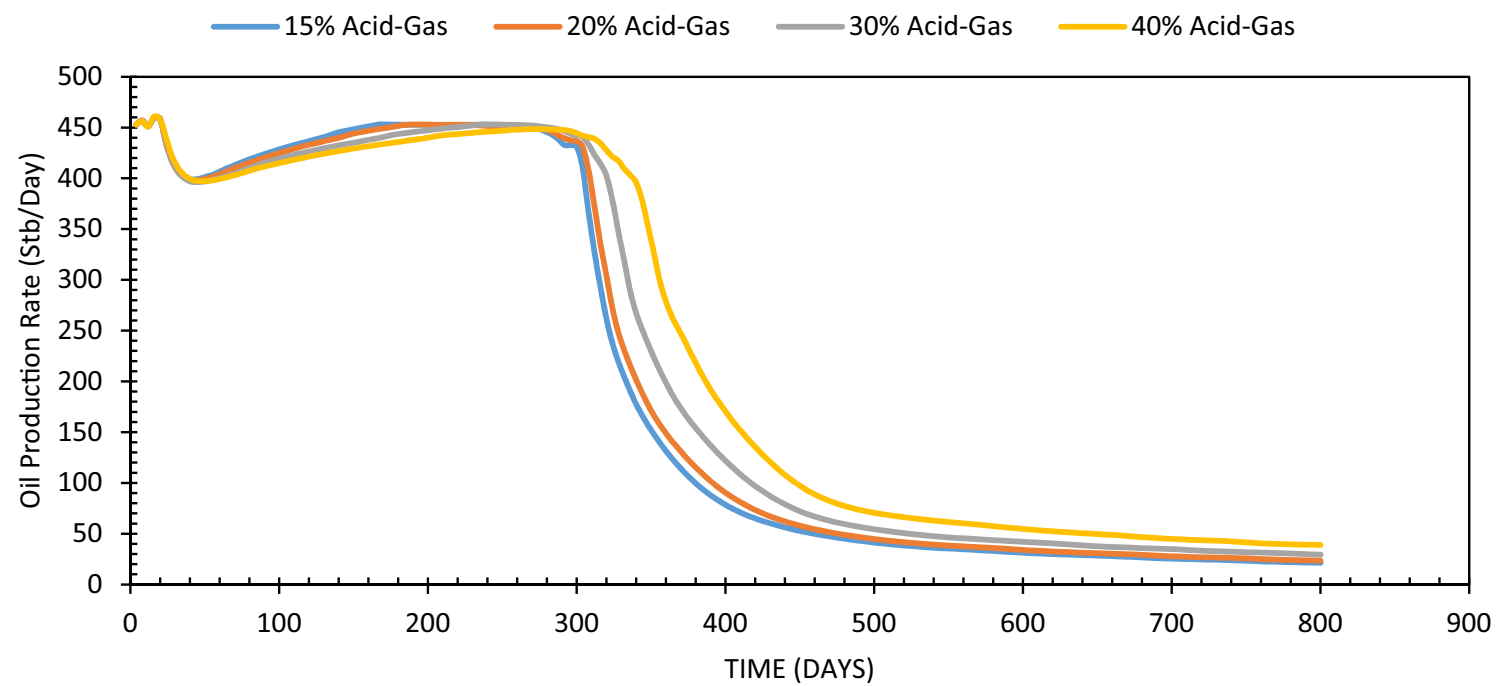

Fig. 9 Comparison of the effect of acid gas composition on oil production rate

is producing under natural depletion before injection starts. For the base case, as the pressure support starts at around day 100 , there is a plateau gas production, while for $40 \%$ acid gas, the gas production did not stabilize until the gas breakthrough. Figure 11 shows the change in gas viscosity with the increased acid gas concentration. This gives a clearer picture of the production profile of both gas and oil. This figure shows that the gas viscosity increases as acid gas concentration is increased. The increase in gas viscosity is the consequence of miscible development resulting in a reduction of oil viscosity.

This reduction is the result of oil swelling or expansion of the under-saturated fluid by the addition of dissolved gas at higher pressures, which lightens the oil and consequently decreases the oil viscosity. This is why $40 \%$ of the acid gas profile did not reach a plateau production until gas breakthrough. As a result, more gas dissolving in oil means less gas is coming out of solution.

Figures 12 and 13 show the oil production rate and recovery efficiency, respectively, for the different cases of injection gas compositions that were also considered. Case one was when only pure $\mathrm{CO}_{2}$ was injected into the reservoir. When compared to the base case scenario, there was a $14.38 \%$ increase in the oil recovery efficiency. There was also an increase in the plateau period for the production rate profile, and this was due to the increase in the injection gas viscosity. For case two, the injection gas contains only $\mathrm{C}_{1}(50 \%)$ and acid gas (50\%). With the decrease in the $\mathrm{C}_{1}$ 


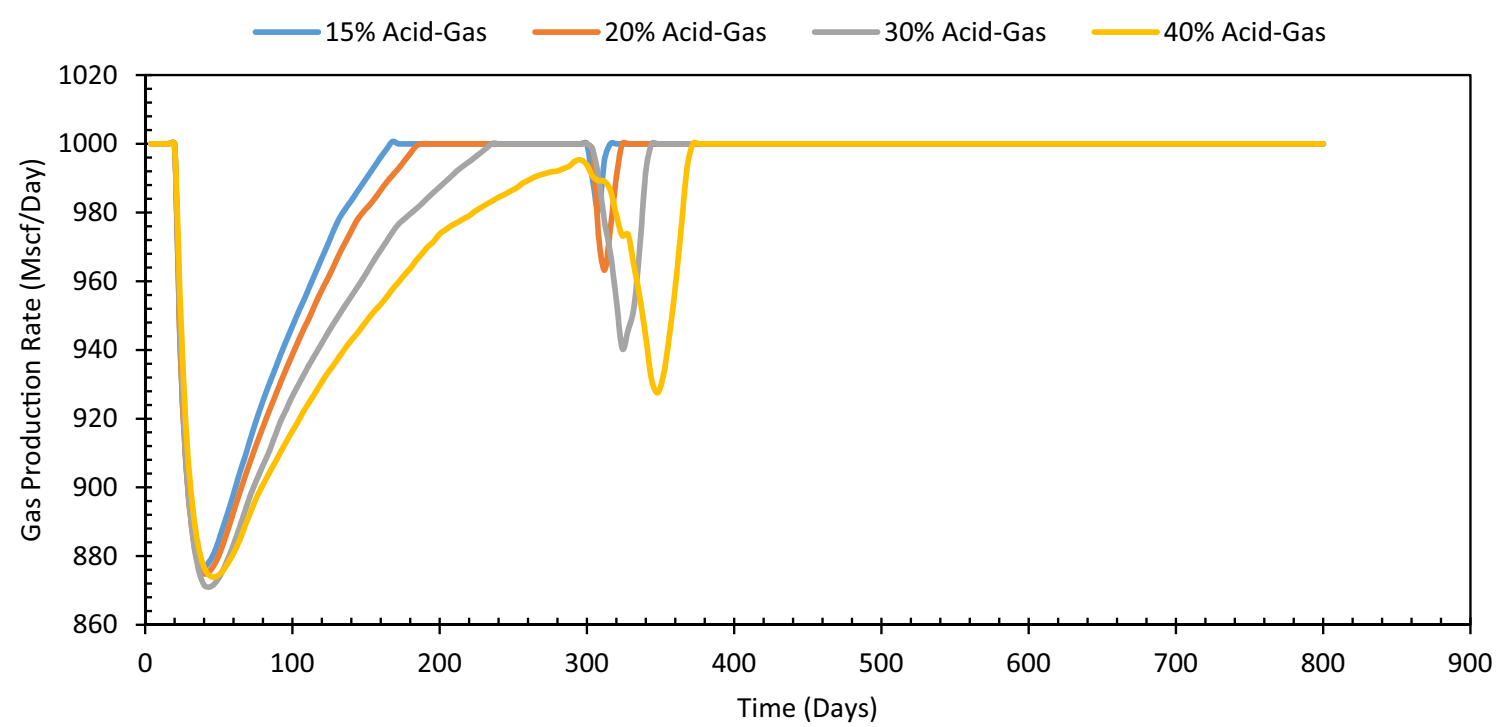

Fig. 10 Comparison of the effect of acid gas composition on gas production rate

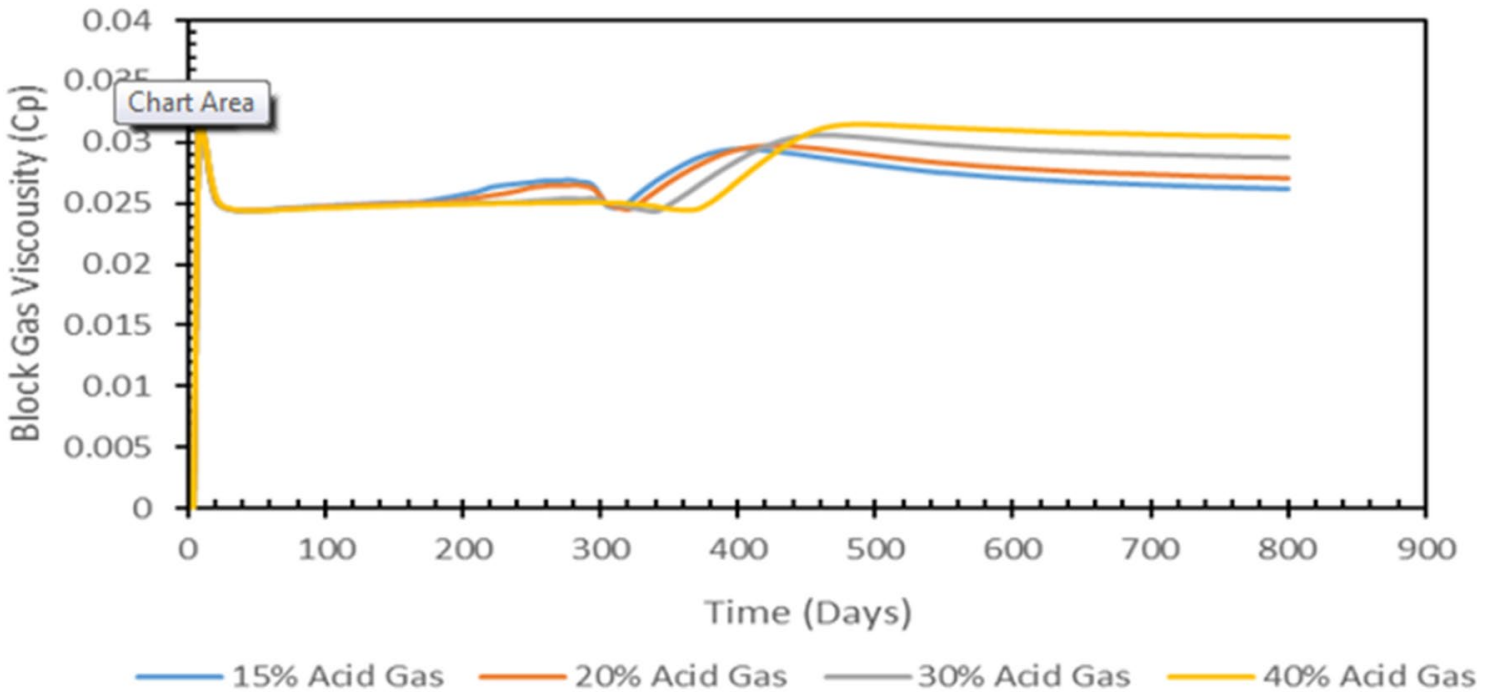

Fig. 11 Effect of acid gas composition on gas viscosity in the production block

composition in the injection gas as compared to the base case, there was $13.40 \%$ increase in the oil recovery. This was due to the increase in the injection gas viscosity, and as a result of this, it led to an increase in the sweep efficiency. The increase in the viscosity of the injection gas increased the plateau production period by 50 days as compared to the base case scenario.

Case three was characterized with the injection of pure acid gas into the reservoir with $\mathrm{CO}_{2}$ and $\mathrm{H}_{2} \mathrm{~S}$ having equal proportion $\left(50 \% \mathrm{CO}_{2}\right.$ and $\left.50 \% \mathrm{H}_{2} \mathrm{~S}\right)$. This case had same recovery efficiency like when only pure $\mathrm{CO}_{2}$ was used. It had a recovery of about $91 \%$. But due to the viscous nature of acid gas, this case had a longer plateau period as compared to case one when only pure $\mathrm{CO}_{2}$ injection was carried out which resulted in an increase in the aerial sweep efficiency. Another advantage of this was that the acid gas achieved miscibility with the reservoir oil at lower pressure as compared to the pure $\mathrm{CO}_{2}$ injection case.

\section{Effect of gas injection rate}

Figure 14 shows how the gas injection rate affects oil production rate. It was observed that there was an early gas breakthrough for rate 2000 and 3000 Mscf. This could be due to the increase in driven force as the injection rate increases. There was no noticeable change when the 
Fig. 12 Oil production rate for the different injection gas composition
Fig. 13 Oil recovery efficiency for the different injection gas composition
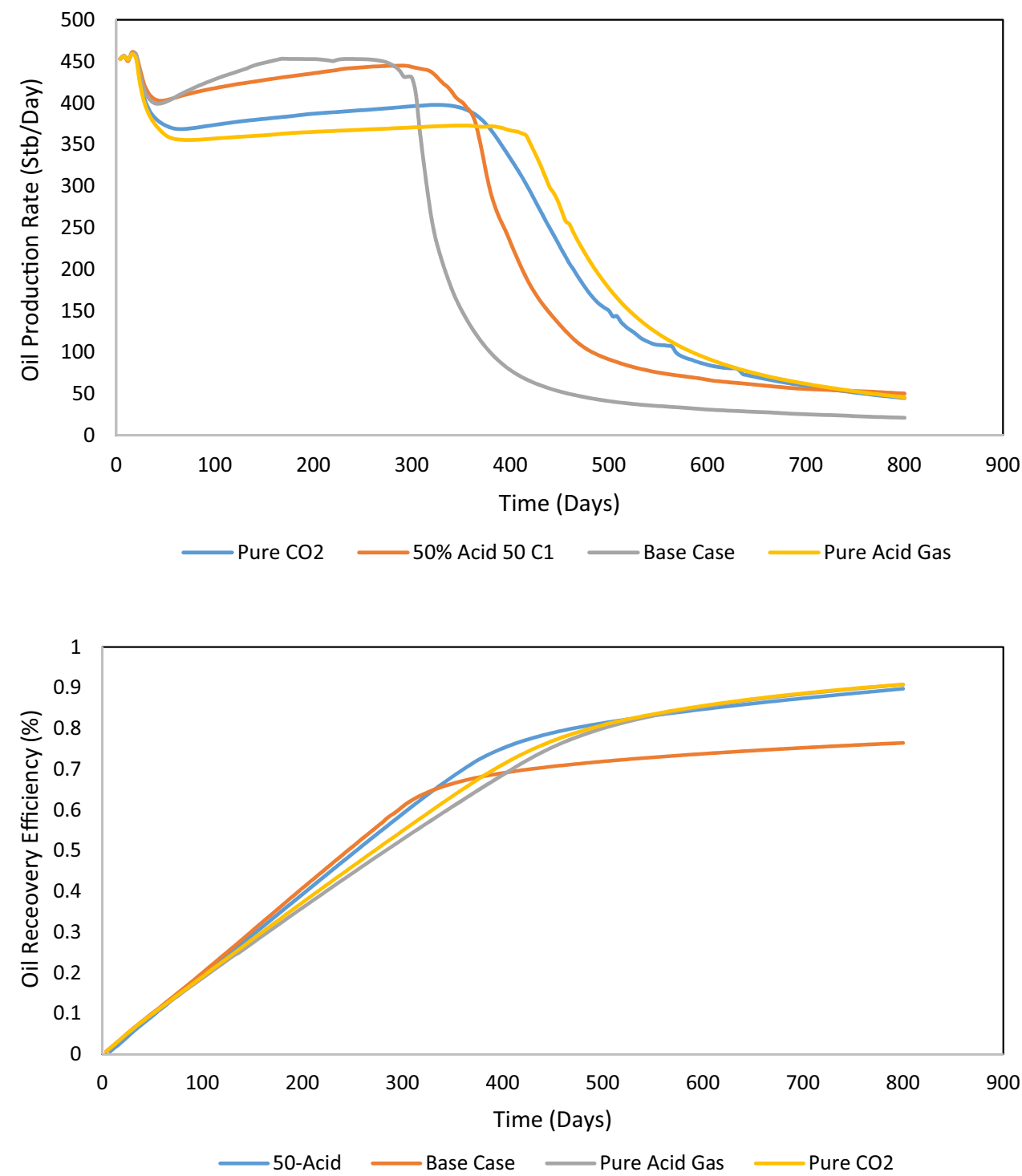

injection rate increased above 2000 Mscf. This is because the injection well is constrained using two parameters (injection rate and pressure). Figure 15 shows the injection rate builds up over time. From the result, it is seen that the rate is gradually building up to the constrained rate and maintained throughout the simulation time for $500 \mathrm{Mscf}$ and $1000 \mathrm{Mscf}$, while for 2000 and $3000 \mathrm{Mscf}$, the rate gradually builds up until the pressure support kicks in. But the rate does exceed 1500 Mscf which is maintained until the gas breakthrough after which rate starts declining until it reaches $1000 \mathrm{Mscf}$. This further shows that the current injection pressure does not support any rate above 1500 Mscf. The rate of decline in the oil production rate observed after breakthrough was due to the decrease in the pressure support.

Figure 16 is used to investigate how the volume of gas injected affects oil recovery efficiency. The result clearly shows that the volume of gas injected is directly proportional to oil recovery efficiency. The result is consistent with the findings of Comberiati and Zammerilli (2000) which also showed an increment in oil production with increasing flood volume.

\section{Injection pressure effect}

Figure 17 shows the effect of gas injection pressure on oil recovery efficiency. It is clearly seen that there is an incremental oil recovery as a result of an increase in injection pressure. This increment in recovery is attributed to the fact that the higher the injection pressure, the more the tendency to attain miscibility. A noticeable change was observed due to the fact that the reservoir attained miscibility as the injection pressure was increased beyond 2500 psi. Figure 18 shows the oil production rate for different injection 
Fig. 14 Comparison of effect of gas injection rate on oil production rate

Fig. 15 Gas injection rate versus time

Fig. 16 Cumulative gas injected versus oil recovery efficiency
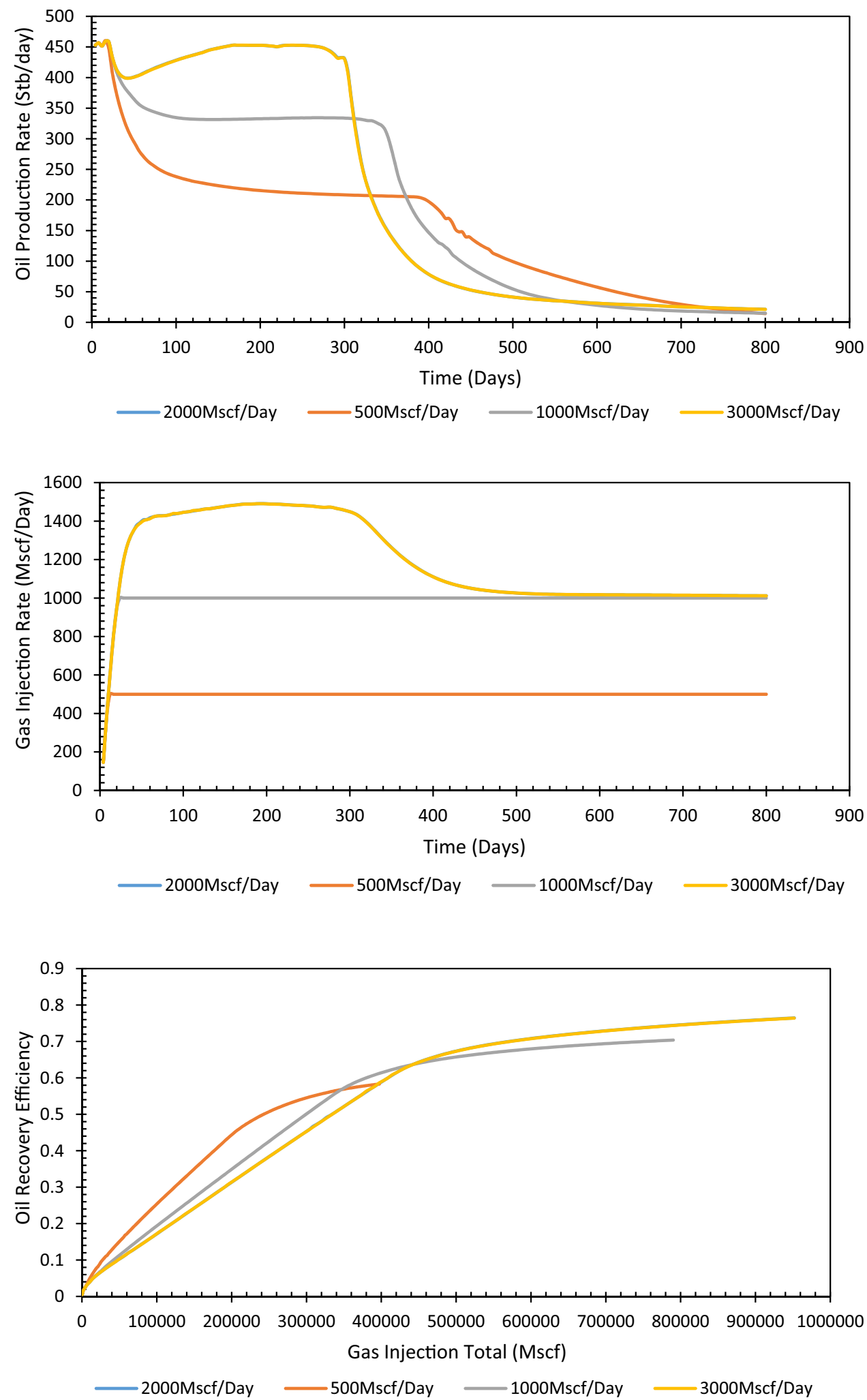

pressures. It is seen that the attainment of miscibility and increment in the injection pressure lead to an increment in the production rate. According to the figure, for the high case, the pressure support was almost immediate, while for the base case, the pressure support did not kick in until 52 days of continuous gas injection. The high case shows an early breakthrough time, but the difference as compared with the base case is marginal which further supports the 
Fig. 17 Effect of gas injection pressure on oil recovery efficiency
Fig. 18 Effect of gas injection pressure on oil production rate
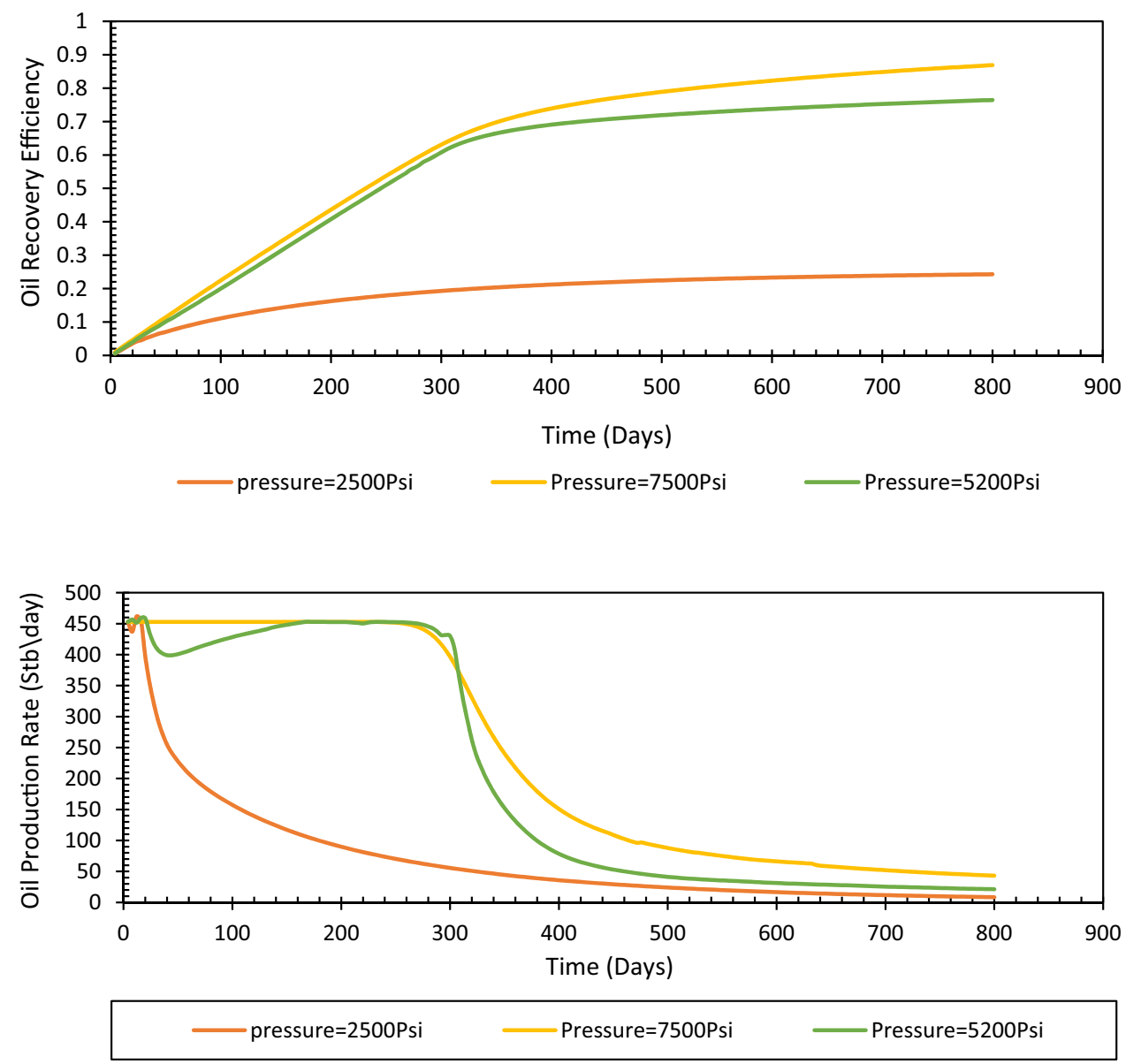

Fig. 19 Effect of gas injection pressure on the injection rate

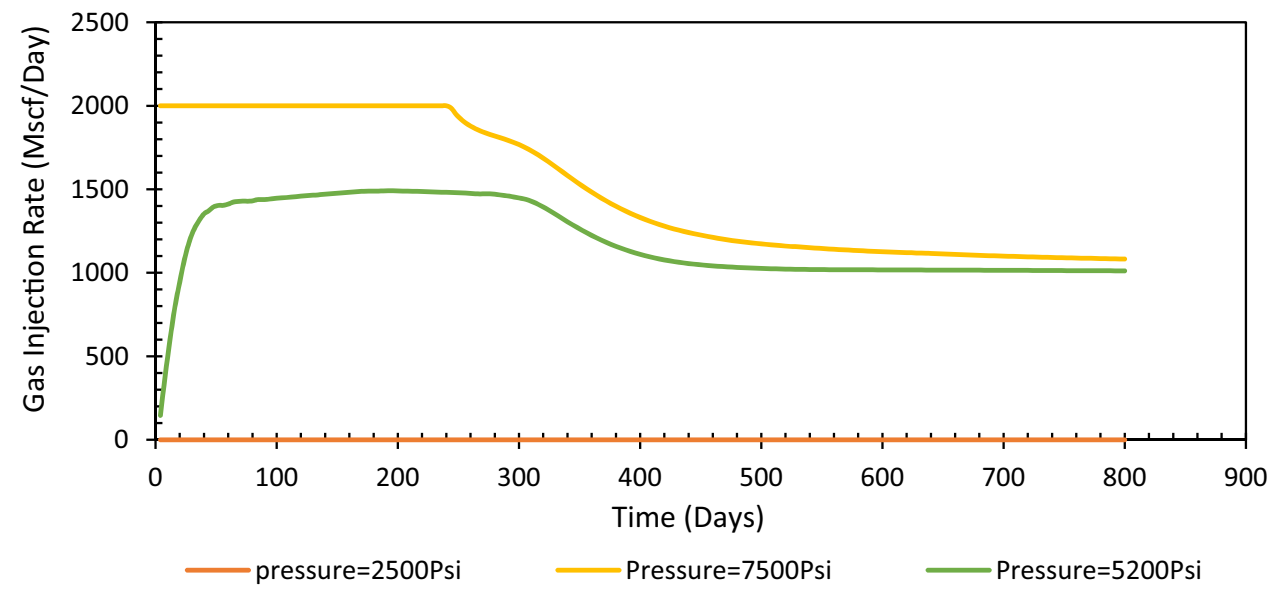

argument that the economy may not support the incremental recovery from the high case.

Figure 19 shows the gas injection rate at different injection pressures. The figure shows how injection pressure affects the gas injection rate. For the high case model, a rate of 2000 Mscf was maintained until the gas breakthrough. After that, there was a steady decline in the rate until it reached $1000 \mathrm{Mscf}$. This effect was seen during the injection rate study which further proves that the injection rate is directly proportional to injection pressure. This is due to the fact that high injection pressure means the driven force is high which translates to high gas velocity. It shows that for this study, the 1000 Mscf rate is the optimal injection rate. 


\section{Conclusion}

- In conclusion, sour gas injection for enhanced oil recovery has supreme performance as compared to other gases used for miscible gas flooding EOR.

- Acid gas lowered the MMP of the process significantly resulting in more oil recovery and low operational cost for the process.

- Injection parameters such as the minimum miscibility pressure, acid gas concentration, injection pressure and injection rate had effect on the overall performance of the recovery process.

- The success of the miscible sour gas injection EOR can be attributed to the variation in fluid viscosities toward lower mobility ratios during injection. The injection gas lowers the oil viscosity substantially. This reduction is as the result of oil swelling or expansion of the under-saturated fluid by the addition of dissolved gas at higher pressures, which lightens the oil and consequently decreases the oil viscosity.

- The increase in the acid gas composition led to an increase in the oil recovery efficiency and the gas breakthrough time.

Open Access This article is distributed under the terms of the Creative Commons Attribution 4.0 International License (http://creativeco mmons.org/licenses/by/4.0/), which permits unrestricted use, distribution, and reproduction in any medium, provided you give appropriate credit to the original author(s) and the source, provide a link to the Creative Commons license, and indicate if changes were made.

\section{Appendix}

See Tables 7, 8 and 9.

\section{References}

Abou-Sayed AS, Zaki K, Summers C (2004) Management of sour gas by underground injection-assessment, challenges and recommendations. SPE Soc Pet Eng. https://doi.org/10.2118/86605-ms

Al-Hadhrami AK, Darrell DW, Deinum G, Harry S (2007) The design of the first miscible sour gasflood project in Oman. In: IPTC: international petroleum technology conference. https://doi. org/10.2523/iptc-11396-ms

Battistelli A, Ceragioli P, Marcolini M (2011) Injection of acid gas mixtures in sour oil reservoirs: analysis of near-wellbore processes with coupled modelling of well and reservoir flow. Transp Porous Med 90(1):233-251. https://doi.org/10.1007/s11242-010-9685-6

Benham AL, Dowden E, Kunzman JW (1960) Miscible fluid displacement-prediction of fluid miscibility. Pet Trans AIME 219:8

Bennion DB, Thomas FB, Bennion DW, Bietz RF (1999) Formation screening to minimize permeability impairment associated with acid gas or sour gas injection/disposal. In: Annual technical meeting, Petroleum Society of Canada. https://doi. org/10.2118/99-13-56

Bhatti AA, Raza A, Mahmood SM et al (2019) Assessing the application of miscible $\mathrm{CO} 2$ flooding in oil reservoirs: a case study from Pakistan. J Pet Explor Prod Technol. https://doi.org/10.1007/ s13202-018-0504-x

Ceragioli P, Gianelli G (2008) Alteration of thermodynamic equilibria and fluids-rock interactions during acid gas injection into a carbonate sour oil reservoir. SPE Soc Pet Eng. https://doi. org/10.2118/113920-ms

Chen, Z, Liao X, Zhao X, Chen C, Zhu L, Zhang F, Mu L, Zhou X (2016) Optimization of injection and production parameters for sour gas storages: a case study. In: OTC: offshore technology conference. https://doi.org/10.4043/26686-ms

Christiansen RL, Haines K (1987) Rapid measurement of minimum miscibility pressure with the rising-bubble apparatus. SPE Reserv Eng. https://doi.org/10.2118/13114-pa

Chugh S, Behrend J, McKishnie RA (2006) Development of the Strasshof Tief sour gas field including acid gas injection into adjacent producing sour gas reservoirs. In: SPE Europec/EAGE annual conference and exhibition. SPE: Society of Petroleum Engineers. https://doi.org/10.2118/100328-ms

Comberiati JR, Zammerilli AM (2000) Effects of petroleum-reservoir conditions on oil recovery by carbon dioxide injection; DOE/ METC/TPR-83-4 (DE83008455); U.S. Department of Energy: Morgantown, WV, USA

Eakin, BE, Mitch FJ (1988) Measurement and correlation of miscibility pressure of reservoir oil. In: SPE annual technical conference and exhibition, Houston. SPE

Elsharkawy AM, Poettmann FH, Christiansen LR (1992) Measuring minimum miscibility pressure: slim-tube or rising-bubble method? In: SPE/DOE enhanced oil recovery symposium. SPE: Society of Petroleum Engineers. https://doi.org/10.2118/24114-ms

Ghoodjani E, Bolouri SH (2011) Experimental study of $\mathrm{CO}_{2}$-EOR and $\mathrm{N}_{2}$-EOR with focus on relative permeability effect. J Pet Environ Biotechnol 2:106. https://doi.org/10.4172/2157-7463.1000106

Glaso O (1985) Generalized minimum miscibility pressure correlation (includes associated papers 15845 and 16287). https://doi. org/10.2118/12893-pa

Green DW, Willhite PG (1998) Enhance oil recovery, SPE. SPE, USA

Hawez H, Ahmed Z (2014) Enhanced oil recovery by $\mathrm{CO}_{2}$ injection in carbonate reservoirs. WIT Trans Ecol Environ 186:547-58. https ://doi.org/10.2495/esus140481 (PDF) Efficiency of enhanced oil recovery by injection of low-salinity water in barium-containing carbonate reservoirs. https://www.researchgate.net/publicatio n/326425502_Efficiency_of_enhanced_oil_recovery_by_injec tion_of_low-salinity_water_in_barium-containing_carbonate_ reservoirs. Accessed 14 Feb 2019

Haynes B, Kaura NC, Faulkner A (2008) Life cycle of a depletion drive and sour gas injection development: Birba A4c Reservoir, South Oman. In: IPTC: international petroleum technology conference. https://doi.org/10.2523/iptc-12175-ms

Holm LW, Josendal VA (1974) Mechanisms of oil displacement by carbon dioxide. J Pet Technol 26(12):1427-1438. https://doi. org/10.2118/4736-pa

Khan C, Amin R, Madden G (2013) Effects of Co2 and acid gas injection on enhanced gas recovery and storage. J Pet Explor Prod Technol 3(1):55-60. https://doi.org/10.1007/s13202-012-0044-8

Lake LW (1989) Enhanced oil recovery. Prentice-Hall, Englewood Cliffs

Metcalfe RS, Fussell DD, Shelton LJ (1973) A multicell equilibrium separation model for the study of multiple contact miscibility in rich-gas drives. Soc Pet Eng J 13:147-155. https://doi. org/10.2118/3995-pa

Nwidee LN, Theophilus S, Barifcani A, Sarmadivaleh M, Iglauer S (2016) EOR processes, opportunities and technological 
advancements. Chem Enhanc Oil Recov Pract Overv. https://doi. org $/ 10.5772 / 64828$

Orr FM, Silva MK (1987) Effect of oil composition on minimum miscibility pressure - part 2: correlation. SPE Reserv Eng 2:479-491. https://doi.org/10.2118/14150-pa

Orr FM, Silva MK, Lien CL, Pelletier MT (1982) Laboratory experiments to evaluate field prospects for $\mathrm{CO} 2$ flooding. J Pet Technol 34:888-898

Xue Y, Vo M, Yu Y, Singleton F, Zhang J (2019) Water disposal management in a sour gas field development in Sichuan. In: Shemwell $\mathrm{S}$, Lin J (eds) Proceedings of the international petroleum and petrochemical technology conference 2018. IPPTC 2018, Springer, Singapore
Yuan H, Johns RT, Egwuenu AM, Dinoruk B (2004) Improved MMP correlations for $\mathrm{CO}_{2}$ floods using analytical gas flooding theory. Paper SPE 89359 presented at SPE/DOE fourteenth symposium on improved oil recovery held in Tulsa, Oklahoma, USA, April $17-21$

Publisher's Note Springer Nature remains neutral with regard to jurisdictional claims in published maps and institutional affiliations. 